\title{
EKSISTENSI KEWENANGAN KOMISI YUDISIAL REPUBLIK INDONESIA DALAM UUD RI TAHUN 1945 (Studi Perbandingan Komisi Yudisial Indonesia dan Peru)
}

\author{
Nunik Nurhayati, S.H.,M.H. ${ }^{1}$ \\ nn123@ums.ac.id
}

\begin{abstract}
Abstrak

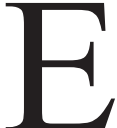
tika kehidupan berbangsa adalah etika penyelenggaraan negara yang berkaitan dengan perilaku integritas hakim sebagai pelaksana kekuasaan kehakiman yang merdeka untuk menyelenggarakan pengadilan guna menegakkan hukum dan keadilan. Pada amandemen ketiga UUD 1945, pembahasan mengenai pengawasan terhadap hakim menjadi isu yang mendesak, sehingga akhirnya disepakati adanya perubahan dan penambahan pasal yang berkaitan dengan Komisi Yudisial pada pasal 24 B UUD 1945 yang kemudian pada tahun 2004 lahirlah UU No. 22 Tahun 2004 tentang Komisi Yudisial junto UU No. 18 Tahun 2011. Dalam pasal 24 B ayat (1) UUD Tahun 1945, Komisi Yudisial bersifat mandiri. Namun pada kenyataannya, pengertian mandiri disini tidak sepenuhnya mandiri karena berdasarkan UU Komisi Yudisial, kewenangan KY hanya sebatas memberikan rekomendasi terkait penegakan etika hakim kepada Mahkamah Agung (MA) untuk ditindaklanjuti. Konsekuensinya, pada tahun 2015 kemarin, dari 116 rekomendasi yang diberikan KY ke MA hanya 45 rekomendasi yang ditindaklanjuti oleh MA. Berbeda dengan Negara Peru, KY dibentuk pada tahun 1993 seiring dengan amandemen terhadap konstitusinya karena dilatarbelakangi oleh adanya ketidakpercayaan public terhadap peradilan, terutama independensi hakim. Lembaga ini diatur dalam satu bab khusus dalam konstitusi Peru, yaitu Bab IX tentang Del Consejo National De La Magistratur. Secara substansi, Bab IX mengatur tentang fungsi lembaga dalam struktur ketatanegaraan Peru dan keanggotaan lembaga. Pengaturan mengenai KY Peru dalam Konstitusi dilakukan secara definitive, sehingga mengakibatkan kedudukannya yang sangat kuat dalam system ketatanegaraan Peru dan dibentuk sebagai lembaga yang independen, lepas dari segala pengaruh bahkan intervensi dari kekuasaan lain, termasuk kekuasaan kehakiman sekalipun. Maka, yang bisa dilakukan Indonesia adalah penguatan lembaga KY dalam melaksanakan wewenangnya dengan diatur dalam peraturan perundang-undangan agar keputusan Komisi Yudisial dalam penegakan etika hakim bersifat final dan mengikat tidak hanya berupa rekomendasi yang masih harus ditindaklanjuti oleh Mahkamah Agung.
\end{abstract}

Kata Kunci: Kewenangan, Komisi Yudisial, UUD RI Tahun 1945

\section{PENDAHULUAN}

Salah satu bagian penting dari etika kehidupan berbangsa adalah etika penyelenggaraan negara yang berkaitan dengan perilaku berintegritas dari para penyelenggara Negara, dalam hal ini adalah hakim sebagai pelaksana kekuasaan kehakiman yang merdeka untuk menyelenggarakan pengadilan guna menegakkan hukum dan keadilan. Maka sudah sewajarnya jika etika hakim sebagai pelaksana kekuasaan kehakiman harus dijaga. Di Paris misalnya, lembaga Negara yang berwenang untuk mengawasi peradilan dan menegakkan etika para hakim sudah ada sejak tahun 1800 .

1 Dosen Di Fakultas Hukum Universitas Muhammadiyah Surakarta, email:nn123@ums.ac.id 
Di Indonesia sendiri, pembentukan lembaga pengawas peradilan sebenarnya sempat digagas sebelum terbentuknya Komisi Yudisial. Misalnya, ada wacana pembentukan Majelis Pertimbangan Penelitian Hakim (MPPH) dan Dewan Kehormatan Hakim (DKH). MPPH yang telah diwacanakan sejak tahun 1968, berfungsi memberikan pertimbangan dan mengambil keputusan terakhirmengenai saran-saran dan/atau usul-usul yang berkenaan dengan pengangkatan, promosi, kepindahan, pemberhentian, dan tindakan/hukuman jabatan para hakim yang diajukan, baik oleh Mahkamah Agung maupun oleh Menteri Kehakiman. Sayangnya, ide tersebut menemui kegagalan sehingga tidak berhasil menjadi materi muatan Undang-Undang Nomor 14 Tahun 1970 tentang KetentuanKetentuan Pokok Kekuasaan Kehakiman. Sementara Dewan Kehormatan Hakim (DKH) yang tertuang dalam Undang-Undang Nomor 35 Tahun 1999 berwenang mengawasi perilaku hakim, memberikan rekomendasi mengenai perekrutan, promosi, dan mutasi hakim, serta menyusun kode etik (code of conduct) bagi para hakim.

Awalnya, keberadaan Komisi Yudisial sebagai institusi penegak kode etik hakim ini berada di dalam struktur Mahkamah Agung. Namun karena perkembangan kebutuhan zaman, dan juga atas pengaruh perkembangan di dunia pada akhir abad ke-20 dan awal abad ke-21 dengan munculnya ide-ide pembentukan komisi-komisi yudisial sebagai 'lembaga eksternal' di lingkungan pengadilan di banyak negara, maka Indonesia mengadopsi ide Komisi Yudisial itu dengan mencantumkan keberadaannya dalam UUD 1945.

Pencantuman Komisi Yudisial ini dalam ketentuan konstitusi menyebabkan lembaga ini menjadi sangat 'lux', dan bahkan untuk sebagian orang dianggap berlebihan, karena dipengaruhi oleh emosi sesaat sebagai akibat kekecewaan publik yang luas terhadap kinerja peradilan, khususnya Mahkamah Agung, di masa-masa krisis yang kemudian dijawab dengan dilakukannya reformasi yang berpuncak pada agenda amandemen konstitusi pada tahun 1999-2002. ${ }^{2}$

Pada sidang tahunan MPR tahun 2001 mengenai amandemen ketiga UUD 1945, pembahasan mengenai pengawasan terhadap hakim menjadi isu yang mendesak, sehingga akhirnya disepakati adanya perubahan dan penambahan pasal yang berkaitan dengan Komisi Yudisial pada pasal 24 B yang bunyi ayatnya adalah sebagai berikut:

1. Komisi Yudisial bersifat mandiri yang berwenang mengusulkan pengangkatan hakim agung dan mempunyai wewenang lain dalam rangka menjaga dan menegakkan kehormatan, keluhuran martabat, serta perilaku hakim.

2. Anggota Komisi Yudisial harus mempunyai pengetahuan dan pengalaman di bidang hukum serta memiliki integritas dan kepribadian yang tidak tercela.

3. Anggota Yudisial diangkat dan diberhentikan oleh Presiden dengan persetujuan Dewan Perwakilan Rakyat.

4. Susunan, kedudukan, dan keanggotaan Komisi Yudisial diatur dengan undang-undang.

Momentum amandemen konsitusi saat itu berhasil dimanfaatkan oleh kaum reformis untuk mendesak ide pembentukan Komisi Yudisial, sehingga Komisi Yudisial resmi menjadi lembaga konstitusional yang untuk pertama kali nya dibentuk pada tahun 2004 berdasarkan UU No. 22 Tahun 2004 tentang Komisi Yudisial yang kemudian diubah dengan UU No. 18 Tahun 2011.

Selain itu, Pada tahun 2001, Majelis Permusyawaratan Rakyat juga mengesahkan Ketetapan MPR No. VI/MPR/2001 tentang Etika Kehidupan Berbangsa. Dimana TAP MPR tersebut adalah salah satu dari ketigabelas TAP MPR yang masuk dalam hierarki Peraturan Perundang-undangan seperti diatur dalam UU Nomor 12 Tahun 2011 Tentang Pembentukan Peraturan PerundangUndangan. Sehingga sudah menjadi konsekuensi sebuah hierarki, bahwa TAP MPR ini harus disesuaikan dengan peraturan perundang-undangan di Indonesia.

2 Jimly Asshiddiqie. Komisi Yudisial Baru Dan Penataan Sistem Infra-Struktur Etika Berbangsa Dan Bernegara. http://www.jimly.com/ 


\section{URGENSI PENEGAKAN ETIKA HAKIM}

Doktrin negara berdasarkan atas hukum (de rechstaat) yang dianut di Indonesia ditandai dengan adanya pasal 1 ayat (3) UUD 1945, bahwa negara Indonesia adalah negara hukum. Banyak ahli yang menempatkan kekuasaan kehakiman yang merdeka sebagai ciri utama dari doktrin negara hukum. Penyelesaian sengketa hukum oleh suatu kekuasaan kehakiman yang merdeka (hakim yang bebas), merupakan dasar bagi berfungsinya sistem hukum yang baik. ${ }^{3}$ Lebih jauh lagi, adanya kekuasaan kehakiman yang merdeka merupakan sebuah jaminan penting bagi masyarakat bahwa pemerintah akan bertindak sesuai dengan hukum yang berlaku.

Namun Bagir Manan juga telah mengingatkan bahwa kekuasaan kehakiman yang merdeka yang berwujud kebebasan hakim dalam memutus perkara tidaklah tanpa resiko. Kemungkinan untuk menyalahgunakan kekuasaan dan bertindak sewenang-wenang atas nama kebebasan hakim sangat besar terjadi. Sehingga menurut beliau perlu dibuat batasan-batasan tertentu tanpa mengorbankan prinsip kebebasan sebagai hakikat kekuasaan kehakiman, pembatasan tersebut diantaranya: ${ }^{4}$

1. Hakim memutus menurut hukum

2. Hakim memutus semata-mata untuk memberikan keadilan

3. Dalam melakukan penafsiran konstruksi atau penemuan hukum, hakim harus tetap berpegang teguh pada asas-asas umum hukum (general principle of law) dan asas keadilan yang umum (the general principles of nature justice).

4. Harus diciptakan suatu mekanisme yang memungkinkan menindak hakim yang sewenangwenang untuk menyalahgunakan kebebasannya

Berkaitan dengan pembatasan keempat, Bagir Manan menjelaskan tindakan yang dimaksud tidak mengenai fungsi yustisialnya. Tidak ada suatu kekuasaan yang dapat menindak hakim karena putusannya dianggap kurang adil. Tindakan terhadap hakim hanya sebatas perilaku pribadinya yang merugikan negara atau menurunkan martabat kekuasaan kehakiman.

Nyatanya, kekhawatiran yang dijabarkan oleh Bagir Manan terbukti dalam tataran praktis. Misalnya, Kartini Marpaung, hakim pengadilan tipikor semarang yang tertangkap tangan menerima suap. Arsyad Sanusi, hakim konstitusi yang di tetapkan melanggar kode etik dan perilaku hakim dikarenakan pertemuan anggota keluarganya dan bawahannya dengan pemohon uji materi Undangundang Nomor 32 Tahun 2004 Tentang Pemerintahan Daerah. ${ }^{5}$

\section{EKSISTENSI KEWENANGAN KOMISI YUDISIAL RI DALAM UUD TAHUN 1945}

Keberadaan Komisi Yudisial yang ditopang keberadaannya dengan pengaturan yang sangat kuat dalam Pasal 24B UUD 1945, tidak diimbangi oleh rumusan kewenangan yang memadai dalam skema peran yang bersifat proporsional antar cabang dan antar fungsi-fungsi kekuasaan negara. Komisi Yudisial hanya diberi peran sebagai (i) perekruit dan pengusul calon-calon hakim agung, dan (ii) bersama-sama Mahkamah Agung menjadi penegak kode etik hakim di lingkungan Mahkamah Agung, serta (iii) bersama-sama Mahkamah Agung terlibat dalam pendidikan dan pelatihan hakim. Pernah ada keinginan untuk memperluas jangkauan peran Komisi Yudisial dalam penegakan kode etik hakim konstitusi dan hakim agung. Namun, oleh karena idenya dikembangkan secara reaktif tanpa didukung oleh keterpaduan konsepsional terkait dengan aturan-aturan konstitusional secara utuh, maka ide semacam itu belum dapat diterima sebagai sesuatu yang sejalan dengan desain konstitusional yang berlaku sekarang. ${ }^{6}$

Hingga kini, ternyata tidak sedikit hasil pengawasan KY terhadap perilaku hakim tidak

3 Montesquieu, The Spirit of the Law, dalam Bagir manan, kekuasaan kehakiman RepubIik Indonesia, hal 5

4 Ibid hal 12-13

5 http://nasional.kompas.com/read/2011/02/11/14025147/Hakim.Konstitusi.Arsyad.Mundur

6 Umi Illiyina, Pasang Surut Komisi Yudisial:Kreasi, resistensi dan restorasi, Jurnal Konstitusi, Volume 8, Nomor

3, Juni 2011 ISSN 1829-7706 
ditindaklanjuti Mahkamah Agung. Setidaknya ada 15 rekomendasi KY terkait hukuman bagi sejumlah hakim belum ditanggapi oleh MA. ${ }^{7}$ Tidak ditindaklanjutinya rekomendasi KY ke tahap selanjutnya oleh MA merupakan salah satu kelemahan beleid yang menjadi dasar pembentukan KY, yaitu UU Nomor 22 Tahun 2004 tentang Komisi Yudisial. Undang-Undang Nomor 8 Tahun 2011 tentang perubahan UU Nomor 22 Tahun 2004 juga tak memberikan solusi atas persoalan tersebut. Tidak ada sanksi bagi Mahkamah Agung jika tidak menindaklanjuti rekomendasi Komisi Yudisial.

Pasal 22D ayat 3 Undang-Undang Nomor 8 Tahun 2011 mengatur, MA memiliki waktu 60 hari untuk menjatuhi sanksi pada hakim yang melanggar etik dan pedoman perilaku sesuai rekomendasi KY. Beleid itu juga mengatur tiga kategori sanksi yang dapat dijatuhkan KY, yaitu ringan, sedang dan berat. Khusus untuk pemberhentian dengan hak pensiun maupun secara tidak hormat, MA dan KY perlu membentuk Majelis Kehormatan Hakim. Putusan majelis itu wajib diimplementasikan MA dalam waktu 30 hari.

KY tidak mempunyai kewenangan untuk memberikan sanksi pada hakim yang melanggar kode etik. Selama ini, kewenangan KY hanya sebatas memberikan rekomendasi kepada Mahkamah Agung (MA) untuk ditindaklanjuti. KY telah mengeluarkan 116 rekomendasi sanksi terhadap hakim yang dinilai melakukan pelanggaran kode etik selama 2015. Dari jumlah tersebut, hanya 45 rekomendasi yang ditindak lanjuti Mahkamah Agungl:

Hal ini berbeda dengan kewenangan DKPP (Dewan Kehormatan Penyelenggara Pemilu) yang memiliki kewenangan menegakan etika para penyelenggara Pemilu, dimana putusan yang dikeluarkan DKPP bersifat final dan mengikat. Jika KY memiliki kewenangan memberikan keputusan yang mengikat seperti DKPP, maka hakim pun terikat kode etik dengan KY. Sehingga pengawasan terhadap pelanggaran kode etik yang dilakukan hakim oleh KY pun dapat berjalan maksimal.

Lemahnya pengawasan internal dipengaruhi oleh beberapa faktor, yakni: kualitas dan integritas pengawasan yang tidak memadai, proses pemeriksaan disiplin yang tidak transparan, belum adanya kemudahan bagi masyarakat untuk mengadukan dan juga memantau proses serta hasil pengaduan tersebut. Dan ada dua faktor lain yakni semangat membela korps (esprit de corps) dan juga tidak terdapat kehendak yang kuat dari pemimpin lembaga.

Pengawasan terhadap hakim yang lahir pasca rangkaian amandemen UUD 1945 era reformasi tidak sepenuhnya mulus dalam tataran praktik. Pengawasan yang dilakukan Komisi Yudisial terhadap kekuasaan kehakiman yang baru berjalan beberapa tahun, menghasilkan hubungan yang tidak harmonis antara Mahkamah Agung dan Komisi Yudisial. Mahkamah Agung berpendapat bahwa Komisi Yudisial terlalu luas mengartikan tugasnya sebagai pengawas terhadap hakim karena menjadikan putusan sebagai pintu masuk pengawasan hakim dalam menjalankan tugasnya.

Akhirnya, pada tahun 2006 sejumlah hakim agung melakukan permohonan judicial review ke Mahkamah Konstitusi dan meminta Mahmakah Konstitusi membatalkan pasal-pasal yang mengatur mengenai kewenangan Komisi Yudisial untuk melakukan pengawasan terhadap hakim (dan hakim agung).

\section{STUDI PERBANDINGAN KOMISI YUDISIAL INDONESIA DENGAN PERU.}

Pendekatan perbandingan merupakan salah satu cara yang digunakan dalam penelitian normatif untuk membandingkan salah satu lembaga hukum (legal istitution) dari sistem hukum yang satu dengan lembaga hukum (yang kurang lebih sama dari sistem hukum) yang lain. Dari perbandingan tersebut dapat ditemukan unsur-unsur persamaan dan perbedaan kedua sistem hukum itu. ${ }^{9}$

\footnotetext{
7 http://www.cnnindonesia.com/nasional/20150713140324-12-66077/ada-15-rekomendasi-komisi-yudisialyang-belum-direspons-ma/

8 http://jateng.tribunnews.com/2016/04/14/sepanjang-2015-komisi-yudisial-rekomendasikan-116-hakim-dapatsanksi

9 Soerjono Soekanto dalam Bambang Sunggono, Metode Penelitian Hukum, Penerbit PT Raja Grafindo Persada,
} 
Menurut Sunaryati Hartono, dengan melakukan perbandingan hukum akan dapat ditarik kesimpulan bahwa: ${ }^{10}$

1. Kebutuhan-kebutuhan yang universal (sama) akan menimbulkan cara-cara pengauturan yang sama pula; dan

2. Kebutuhan-kebutuhan khusus berdasarkan perbedaan suasana dan sejarah itu menimbulkan cara-cara yang berbeda pula.

Tulisan ini mengambil perbandingan dengan Negara Peru karena Peru memiliki Lembaga Negara sejenis Komisi Yudisial yang diatur dalam konstitusi namun keberadaanya berada diluar kekuasaan kehakiman. Hal ini menjadi menarik karena Komisi Yudisial Peru menjadi benar-benar lembaga Negara yang mandiri untuk menegakkan etika hakim.

Seperti yang sudah dibahas diatas, dalam pasal 24 B ayat (1) UUD RI Tahun 1945 menyatakan bahwa Komisi Yudisial bersifat mandiri yang berwenang mengusulkan pengangkatan hakim agung dan mempunyai wewenang lain dalam rangka menjaga dan menegakkan kehormatan, keluhuran martabat, serta perilaku hakim. Namun pada kenyataannya, pengertian mandiri disini tidak sepenuhnya mandiri karena berdarkan UU Komisi Yudisial, kewenangan KY hanya sebatas memberikan rekomendasi terkait penegakan etika hakim kepada Mahkamah Agung (MA) untuk ditindaklanjuti. Bahkan pada tahun 2015 kemarin, dari 116 rekomendasi yang diberikan KY ke MA hanya 45 rekomendasi yang ditindaklanjuti oleh MA. Hal ini tentunya menjadi sebuah kritikan besar terhadap kewenangan sebuah lembaga Komisi Yudisial yang kedudukannya diatur dalam norma tertinggi Konstitusi. Hal ini bisa jadi dikarenakan kedudukan lembaga KY masih dalam satu bab Kekuasaan Kehakiman dengan MA dan MK walaupun bersifat mandiri.

Berbeda dengan Peru, KY di Negara Peru dibentuk pada tahun 1993 seiring dengan amandemen terhadap konstitusinya. Pembentukan KY di Peru dilatarbelakangi oleh adanya ketidakpercayaan public terhadap peradilan, terutama independensi hakim, dimana politik kekuasaan mengontrol proses peradilan yang berjalan.

KY di Peru bernama Del Consejo National De La Magistratura atau dalam bahasa Inggris disebut The National Judicial Council. Lembaga ini diatur dalam satu bab khusus dalam konstitusi Peru, yaitu Bab IX tentang Del Consejo National De La Magistratur. Secara substansi , Bab IX mengatur tentang fungsi lembaga dalam struktur ketatanegaraan Peru dan keanggotaan lembaga. Pengaturan mengenai KY Peru dalam Konstitusi dilakukan secara definitive, sehingga mengakibatkan kedudukannya yang sangat kuat dalam system ketatanegaraan Peru. ${ }^{11}$

Seperti telah dikemukakan sebelumnya, bahwa pengaturan mengenai Del Consejo National De La Magistratura dalam konstitusi Peru berada diluar bab tentang kekuasaan kehakiman. Hal ini membuktikan bahwa Del Consejo National De La Magistratura dibentuk sebagai lembaya yang independen, lepas dari segala pengaruh bahkan intervensi dari kekuasaan lain, termasuk kekuasaan kehakiman sekalipun.

Sebagai tambahan, komposisi komisioner sebuah lembaga Negara dijadikan sebuah parameter untuk melihat independensi lembaga tersebut. Di Negara Peru, jumlah anggota KY berjumlah tujuh orang dan bisa bertambah menjadi Sembilan orang seperti diatur dalam article 55 Konstitusi Peru. Komposisi anggota KY Peru yaitu:

1. Satu orang dipilih oleh Mahkamah Agung melalui Pemilihan Rahasia dalam suatu rapat;

2. Satu orang dipilih oleh anggota kelompok advokad di Peru, melalui pemilihan rahasia.

3. Satu orang dipilih oleh anggota kelompok advokad di Peru, melalui pemilihan rahasia.

Jakarta, 2007.hal 313

10 Sunaryati Hartono dalam Johnny Ibrahim, Teori dan Metodologi Penelitian HukumNormatif, Bayumedia Publishing, Malang, 2006, hlm.303

11 Komisi Yudisial Republik Indonesia. 2014. Studi Perbandingan Komisi Yudisial di Beberapa Negara. Jakarta: Sekretariat Jenderal Komisi Yudisial Republik Indonesia. Hlm 94. 
4. Dua orang dipilih oleh anggota kelompok professional lainnya di Peru, melalui pemilihan rahasia.

5. Satu orang dipilih oleh Rektor Universitas, melalui pemilihan rahasia.

6. Satu orang dipilih oleh Rektor Universitas, melalui pemilihan rahasia.

Sementara di Indonesia, Berdasarkan Undang-Undang No 18 Tahun 2011 tentang Perubahan atas Undang-Undang Nomor 22 Tahun 2004 tentang Komisi Yudisial, Susunan Keanggotaan Komisi Yudisial sebagai berikut :

1. Komisi Yudisial terdiri atas pimpinan dan anggota.

2. Pimpinan Komisi Yudisial terdiri atas seorang Ketua dan seorang Wakil Ketua yang merangkap Anggota.

3. Komisi Yudisial mempunyai 7 (tujuh) orang anggota.

4. Anggota Komisi Yudisial adalah pejabat negara.

5. Keanggotaan Komisi Yudisial terdiri atas:

a. 2 (dua) orang mantan hakim;

b. 2 (dua) orang praktisi hukum;

c. 2 (dua) orang akademisi hukum; dan

d. 1 (satu) orang anggota masyarakat.

1. Pimpinan Komisi Yudisial dipilih dari dan oleh Anggota Komisi Yudisial.

2 Ketentuan mengenai tata cara pemilihan pimpinan Komisi Yudisial diatur oleh Komisi Yudisial.

\section{PENUTUP}

\section{Simpulan}

Dari pembahasan diatas dapat disimpulkan bahwa semangat reformasi untuk menciptakan peradilan yang bersih dengan terbentuknya sebuah lembaga mandiri yang berwenang mengawasi peradilan dan menegakkan etika hakim, belum bisa terwujud dikarenakan kurangnya eksistensi Komisi Yudisial terutama dalam melaksanakan wewenangnya untuk menjaga dan menegakkan kehormatan, keluhuran martabat, serta perilaku hakim. Hal ini disebabkan karena belum mandirinya Komisi Yudisial dalam memutus peradilan etika para hakim karena keputusannya tidak bersifat final dan mengikat. Keputusan KY terkait hal tersebut hanya berupa rekomendai yang harus ditindaklanjuti oleh Mahkamah Agung. Yang lebih mengkhawatirkan adalah, berdasarkan data yang ada selama tahun 2015, dari 115 rekomendasi yang diberikan KY kepada MA terkait penegakan etika hakim, hanya 54 yang ditindaklanjuti. Hal ini bisa jadi dikarenakan keberadaan kedudukan KY yang masih dalam satu bab kekuasaan kehakiman dengan MA dan MK dalam Konstitusi sehingga Komisi Yudisial belum bisa mejadi lembaga yang independen, lepas dari segala pengaruh bahkan intervensi dari kekuasaan lain, termasuk kekuasaan kehakiman sekalipun seperti di Peru. Dimana, KY di Peru (Del Consejo National De La Magistratura) atau dalam bahasa Inggris disebut The National Judicial Council diatur dalam satu bab khusus dalam konstitusi Peru, yaitu Bab IX tentang Del Consejo National De La Magistratur.

\section{Saran}

Kewenangan Komisi Yudisial dalam menjaga dan menegakkan kehormatan, keluhuran martabat, serta perilaku hakim harus diperkuat. Mengusulkan amandemen UUD 1945 untuk memperkuat Kedudkan KY masih terlalu jauh untuk direalisasikan, padahal urgensi penguatan lembaga KY sudah mendesak dilakukan. Maka, yang bisa dilakukan adalah penguatan lembaga KY dalam melaksanakan wewenangnya bisa diatur dalam perubahan UU Komisi Yudisial agar mengatur keputusan Komisi Yudisial dalam penegakan etika hakim bersifat final dan mengikat seperti lembaga Dewan Kehormatan Penyelenggara Pemilu (DKPP) 
yang menegakan etika para penyelenggara Pemilu seperti KPU dan Bawaslu. Sehingga keputusan KY nantinya tidak hanya berupa rekomendasi yang masih harus ditindaklanjuti oleh Mahkamah Agung.

\section{DAFTAR PUSTAKA}

Bagir Manan. 2001. Kekuasaan Kehakiman Repubiik Indonesia. Jakarta

http://www.lensaindonesia.com/2012/09/24/dalami-kasus-suap-hakim-tipikor-semarang-kpkperiksa-tiga-saksi.html

http://nasional.kompas.com/read/2011/02/11/14025147/Hakim.Konstitusi.Arsyad.Mundur

http://www.cnnindonesia.com/nasional/20150713140324-12-66077/ada-15-rekomendasi-komisiyudisial-yang-belum-direspons-ma/

http://jateng.tribunnews.com/2016/04/14/sepanjang-2015-komisi-yudisial-rekomendasikan-116hakim-dapat-sanksi

Jimly Asshiddiqie. Komisi Yudisial Baru Dan Penataan Sistem Infra-Struktur Etika Berbangsa Dan Bernegara. http://www.jimly.com/

Johnny Ibrahim, 2006. Teori dan Metodologi Penelitian Hukum Normatif, Malang: Bayumedia Publishing

Komisi Yudisial Republik Indonesia. 2014. Studi Perbandingan Komisi Yudisial di Beberapa Negara. Jakarta: Sekretariat Jenderal Komisi Yudisial Republik Indonesia

Soerjono Soekanto dalam Bambang Sunggono, 2007. Metode Penelitian Hukum, Jakarta: Penerbit PT Raja Grafindo Persada

Umi Illiyina, Pasang Surut Komisi Yudisial:Kreasi, Resistensi dan Restorasi, Jurnal Konstitusi, Volume 8, Nomor 3, Juni 2011 ISSN 1829-7706 